\title{
Communication
}

\section{Organic Horticulture in India}

\author{
Sisir Mitra ${ }^{1, *}$ and Hidangmayum Devi ${ }^{2}$ \\ 1 Section Tropical and Subtropical Fruits, International Society for Horticultural Science, \\ Faculty of Horticulture, Bidhan Chandra Krishi ViswaVidyalaya, Mohanpur, B-12/48, Kalyani, Nadia, \\ West Bengal 741252, India \\ 2 Indian Council of Agriculture Research complex for NEH Region, Tripura Centre, Lembucherra, \\ West Tripura 799210, India; lembihort@gmail.com \\ * Correspondence: sisirm@vsnl.net; Tel.: +91-943-217-4249
}

Academic Editor: Douglas D. Archbold

Received: 1 December 2015; Accepted: 27 September 2016; Published: 26 October 2016

\begin{abstract}
During the previous three decades, organic produce has attracted the attention of a growing health-conscious population across the globe. Both international and domestic communities are becoming aware of issues like agrochemical residues, produce quality, and food safety. Worldwide, over 37.5 million ha of land $(0.87 \%$ of total agricultural land) is being managed organically by 1.9 million producers in 164 countries. In addition, there is another 31 million ha certified for wild harvest collection. Global sales of organic products have reached U.S. $\$ 75$ billion, with the U.S. and Europe as the largest consumers. The concept of organic farming is not new to the Indian farming community. Several forms of organic farming are successfully practiced in diverse climates, particularly in rain-fed, tribal mountains, and hilly areas of the country. Many of the forest products of economic importance, such as herbs and medicinal plants are in this category by default. The report of the Task Force on Organic Farming appointed by the Government of India noted the vast areas of the country where limited amounts of synthetic chemicals are used, although they have low productivity, but also which could have unexploited potential for organic agriculture. As of March 2014, India had 4.72 million ha under an organic certification process, including 0.6 million ha of cultivated agricultural land and 4.12 million ha of wild harvest collection forest area. During 2012-2013, India exported 165,262 million tons of organic products across 135 commodities valued at $\$ 312$ million. The domestic market for organic commodities is also growing at an annual growth rate of $15 \%-20 \%$. The crops grown organically include cashew nut, spices, cotton, rice, sugarcane, pineapple, passion fruit, groundnut, sunflower, millet, vegetables, wheat castor, mustard, walnut, tea, coffee, banana, and mango. Institutional support for organic exports from India was created by the launch of the National Program for Organic Production (NPOP) by the Agriculture and Processed Food Export Development Authority (APEDA), Ministry of Commerce. The NPOP supports promotional initiatives, accreditation by inspection and certification agencies, and offers support to agri-business enterprises to facilitate export. India now has 26 accredited certification agencies to facilitate the certification of growers.
\end{abstract}

Keywords: food safety; environmental health; sustainability; organic

\section{Introduction}

In India, historical farming systems were by and large organic, where crop rotation, choice of cultivar for region, and utilization of solar radiation for soil sterilization were used, and soil fertility was maintained through organic manure and symbiotic soil microflora. Food security is not simply a function of production or supply, but also of availability, accessibility, stability of supply, affordability, the provision of adequate quantity and quality, and safe nutritious food at all times [1,2]. In a world 
where consumers are increasingly aware of what they eat and consume, quality and safety have become key issues and unique selling propositions.

Though India experienced the green revolution from a "begging bowl" status to greater abundance with the increased use of synthetic agrochemicals such as fertilizers and pesticides, the adoption of nutrient-responsive high-yielding varieties of crops, and greater exploitation of irrigation potential, the continuous use of these high energy inputs has indiscriminately led to the deterioration of soil health and the environment, and food safety has become a major concern. This fertilizer and pesticide overuse has put forth a question regarding the sustainability of agriculture/horticulture in the long term, calling attention to sustainable production practices which address social, ecological, and economic issues together. Recognizing the impact of the excessive use of chemical fertilizers on soil health and pesticides on human health, there has been an effort to develop integrated management systems. Organic farming addresses soil, human, and environmental health, and is eco-friendly, and thus may be one of the options for sustainability [3].

\section{Organic Farming}

In a very simplistic form, organic farming is the practice of growing crops without the use of synthetic pesticides, herbicides, and fertilizers. Rather, it relies mainly on crop rotation, use of crop residues by soil incorporation of cover crops, and biomass recycling such as composting, animal integration, and biofertilizers to maintain soil health without disturbing the ecological environment in order to obtain sustainably high yields. The Codex Alimentarius commission-a joint body of $\mathrm{FAO} / \mathrm{WHO}$ - defined organic agriculture as a unique production management system which promotes and enhances agro-ecosystem health, including biodiversity, biological cycles, and soil biological activity, accomplished by the use of on-farm agronomic, biological, and mechanical methods and the exclusion of all synthetic off-farm inputs [4]. The International Federation of Organic Agriculture Movements (IFOAM) has formulated four broad principles of organic farming, which are the basic roots for the growth and development of organic agriculture in a global context: (1) health (to sustain and enhance the health of soil, plant, animal, human, and planet as one and indivisible); (2) ecology (attaining ecological balance through the design of farming systems, establishment of habitats, and the maintenance of genetic and agricultural diversity); (3) fairness (to ensure that fairness characterized by equity, respect, justice, and stewardship of the shared world, with regard to the common environment and life opportunities); and (4) care (managing in a precautionary and responsible manner to protect the health and well-being of current and future generations and the environment by adopting appropriate technologies and rejecting unpredictable ones, such as genetic engineering) [4].

\section{Indian Initiatives}

Historically in India, agriculture utilized organic-like practices. Even presently, much of the forest produce of economic importance, such as herbs, medicinal plants, etc., is in this category. India has brought 4.72 million ha under organic certification processes, including 0.6 million ha of cultivated agricultural land and 4.12 million ha for wild harvest collection in forests, as of March 2014 [5]. Sikkim has become India's first fully organic state by implementing organic practices on approximately 75,000 ha of agricultural land [6]. There has been a consistent increase in the number of certified farmers in the country every year. Organic farmers' associations have taken the lead in adopting and spreading technology. Institutional support for organic production was created by the launch of the National Programme for Organic Production (NPOP) by the Agriculture and Processed Food Export Development Authority (APEDA), Ministry of Commerce. The NPOP supports promotional initiatives, accreditation of inspection and certification agencies, and offers support to agri-business enterprises to facilitate export. APEDA has been interacting with the European Union (EU), the United States Department of Agriculture (USDA), Japan, and IFOAM for recognition of equivalence of the Indian quality assurance system. India was recognized for the purpose of equivalence since June 2006 for an unspecified duration, as reported in the Annex III of Regulation 
(EC) 1235/2008. However, the European Union's organic production rules are not formally recognized as equivalent by India.

In 2004, India's Ministry of Agriculture launched a nationwide initiative-the National Project on Organic Farming (NPOF) - with the objective of promoting organic farming in India by facilitating access to organic inputs, streamlining production, facilitating certification, and developing domestic markets for organic commodities. In 2004-2005, a national Centre for Organic Farming was established under the Ministry of Agriculture at Ghaziabad to provide institutional support and to facilitate moving farmers into organic crop production by providing suitable logistics. The National Horticulture Mission launched by India's Department of Agriculture and Cooperation in 2005 offers assistance for transitioning to organic farming of horticultural crops. As a result of these interventions, organic agriculture has seen unexpectedly high growth. By the combined effort of farmers, the government, NGOs, and market forces, the Indian organic movement has reached a stage where it can swiftly move to occupy a desired space in Indian agriculture. Today, India is alongside the EU, the U.S., Japan, Brazil, Argentina, and Switzerland, which have adopted organic standards and put in place an inspection and certification mechanism [7].

\section{Current Status}

India has the largest number of organic producers in the world most with small holdings. During 2013-2014, India exported 135 products valued at \$403 million. Major destinations for organic products from India were the U.S., the EU, Canada, Switzerland, Australia, New Zealand, South-East Asian countries, West Asia, and South Africa. Soybean comprised 70\% of the commodities, and products exported followed by cereals and millets other than basmati rice $(4 \%)$, sugar $(3 \%)$, tea $(2 \%)$, pulses and lentils (1\%), dry fruits (1\%), and spices (1\%) [8].

Organic farming is growing rapidly among Indian farmers and entrepreneurs, especially in low productivity areas, rain-fed zones, hilly areas, and the northeastern states, where fertilizer consumption is less than $25 \mathrm{~kg} / \mathrm{ha} /$ year. Nine states in India have promoted policies and programs on organic farming. Uttrakhand has made organic a thrust for improving its mountain agriculture farm economy and livelihood. Mizoram and Sikkim declared their intentions to move to total organic farming. Karnataka has formulated organic policies, and Maharashtra, Tamil Nadu, and Kerala have supported public-private partnerships for the promotion of organic farming.

\section{Quality Regulation}

Organic agriculture systems and products are required to be certified by accredited agencies to indicate that they have been produced, stored, processed, handled, and marketed in accordance with technical specifications. The organic label is a production process claim, as opposed to a product quality claim. India now has 26 accredited certification agencies to facilitate the certification of growers. In India, the Tea Board, Coffee Board, Spices Board, and Coconut Development Board have developed guidelines for production and certification, and have encouraged the production and export of organic produce and products. Recognizing the need for organic farming, the Ministry of Agriculture has also taken the major initiative that production and certification for domestic markets shall be the responsibility of the Ministry of Agriculture.

There are now over 150 countries in the world exporting certified organic products. Organic trade is expanding at the rate of $15 \%-20 \%$ per year. Over 500 public and private certification bodies now operate in the global organic market place [9]. The many governmental and private standards and technical regulations governing organic production and certification have placed a burden on producers and traders and created barriers for trade on many levels. There is a need for tools to be in place to support equivalency and harmonization in the global organic trade. By cooperation within and among governments and the private sector, trade barriers can be reduced. 


\section{Key Opportunities in India}

India is one of the leading fruit producers in the world, producing about $10 \%$ of the world's fruit production [10]. Most of the produce is consumed fresh and domestically. The main destinations are the Middle East, Europe, and Southeast Asia. India is the largest mango producer in the world; however, a negligible amount of fresh $(42,998.31 \mathrm{MT})$ and processed mangoes are exported due to huge domestic demand [11]. The UK, Netherlands, and Germany have a high demand for organic mangoes, which could be exploited by India. Indian organic banana exports are negligible in relation to the world trade. India needs to follow a two-pronged strategy for increasing organic banana exports. First, it should target the processed organic banana market (pulp, purees, and concentrates), and second, it should focus on the geographically closer Japanese market and the EU [9].

India has good potential for the export of organic pineapples, as three major importing markets are the U.S., EU, and Japan. As is the case with most other fruit exports from India, the prime export destination for Indian grapes is the Middle East, but it offers limited opportunities for organic grapes. The main target destination market for Indian organic grapes is the EU, especially the UK and the Netherlands. Moreover, there is a current consumption trend increasingly favoring organic wine, further increasing the demand for organic grapes. Other organic fruits which could be successfully exported include litchi, passion fruit, pomegranate, sapota, apple, walnut, and strawberry [9].

India is the second largest producer of vegetables in the world after China, followed by the Middle East, Singapore, Malaysia, Sri Lanka, Bangladesh, Nepal, the EU, and Australia [12]. Traditional vegetables like onion, potato, okra, bitter gourd, and green chilies, and non-traditional vegetables like asparagus, celery, paprika, sweet and baby corn, and cherry tomato are all exported. Global demand is increasing for organic vegetables, and Indian organic vegetable producers would be in a position to expand their market in the EU, Australia, and Singapore. India is also the largest producer and exporter of organic tea. With the European Commission having granted "equivalence" status to Indian organic certifying agencies, Indian organic tea producers are in a position to expand their markets in Europe, one of the leading tea consuming regions. Organic coffee is mainly consumed by the developed countries; namely, the U.S., Germany, France, Italy, Japan, and the EU. India accounts for $1 \%$ of the estimated world organic coffee market, so there is exceptional potential to increase its exports in the near future. India currently accounts for over $12 \%$ (in terms of quantity) of the world spice market. The main consumers of organic spices are Germany, the UK, France, Japan, and the U.S. However, organic spices in India represent a very negligible part of total spice production. Organic spices produced by India and having export potential include pepper, ginger, turmeric, cloves, mace, nutmeg, vanilla, cardamom, chili, mustard, tamarind, camboge, thyme, rosemary, oregano, marjoram, parsley, and sage (fresh, dehydrated, and oil). India is a significant supplier of certified organic ingredients to the global organic cosmetics and health care industries, and has a vast area under herbal and aromatic plant production. India is also a significant producer of essential oils in world. Given these advantages, India could become one of the leading suppliers of organic ingredients to the global organic cosmetic and health care industry [13].

\section{Indian Organic Food Market}

India's organic industry is just beginning to gain attention in the market place in urban centers, primarily with small shops and groceries. However, the retail scene in India is beginning to see dramatic changes with the recent development of hyper-markets in most metropolitan cities. Today, every supermarket has an organic food section, and every large city in India has numerous organic food stores and restaurants. This is a huge change considering that the first organic food store in Mumbai was started in 1997. The pattern of organic food consumption in India is much different than in developed countries. In India, consumers prefer organic fruits, vegetables, spices, strawberry, tea, organic marmalade, organic honey, organic butter, and various organic flours. However, there are many consumers who are unaware of the difference between natural and organic food. Many people purchase products labeled as "Natural" thinking that they are organic. However, consumers are not 
aware of the certification system, since certification is not compulsory for domestic retail in India. The overall growth in the market of organic products was estimated at $14 \%$ for spices, $15 \%$ for banana, $14 \%$ for tea, $11 \%$ for rice, $8 \%$ for fruit, $8 \%$ for herbal extracts, $8 \%$ for cotton, and $4.5 \%$ for turmeric [13]. Organic production is not limited to the foods sector, but also applies to significant amounts of organic cotton fiber, garments, cosmetics, functional food products, and body care products.

\section{Conclusions}

India's organic export markets would grow with the support of the industry, the government, and NGOs coming together to work with farmers. The future for markets for organic foods is definitely bright, as it is growing rapidly in the EU, in the U.S. and Canada, and in Japan and Australia, as well as in some developing countries. With growing consumer awareness of food safety, health, and environmental issues, the organic food sector has become an attractive opportunity for export from developing countries.

Acknowledgments: This review article was compiled by collecting information's from university library; hence no fund was required for writing the manuscript.

Author Contributions: Sisir Mitra conceived the idea of reviewing and writing an article on organic horticulture in India. Sisir Mitra and Hidangmayum Devi together collected the information and compiled the article.

Conflicts of Interest: The authors declare no conflict of interest.

\section{References}

1. Boon, E.K. Food Security in Africa: Challenges and Prospects; Encyclopaedia of Life Support Systems (EOLSS): Oxford, UK, 2007.

2. Mclntyre, D.B.; Herren, H.R.; Wakhungu, J.; Watson, R.T. International Assessment of Agricultural Knowledge, Science and Technology for Development_IAASTD, Agriculture at a Cross Road, Global Report; Island Press: Washington, DC, USA, 2009; p. 590.

3. Singh, H.P. Organic Horticulture-Retrospect and Prospect. In Proceedings of the National workshop on Organic Horticulture-Its Production, Processing, Marketing and Export for Sustainability, Bidhan Chandra Krishi Viswavidyalaya, Mohonpur, West Bengal, India, 8-10 June 2007; Bidhan Chandra Krishi Viswavidyalaya: West Bengal, India, 2007; pp. 1-8.

4. FAO. Organic Agriculture; Food and Agriculture Organization of the United Nations: Rome, Italy, 1999.

5. Yadav, A.K. Organic Agriculture at a Glance 2015. Available online: http://krishijagran.com/farm/scenarioin-india/2015/03/Organic-Agriculture-At-a-Glance (accessed on 2 April 2015).

6. Sikkim Becomes India's First Organic State. Available online: http://www.thehindu.com/news/national/ sikkim-becomes-indias-first-organicstate/article8107170.ece (accessed on 14 January 2016).

7. Chadha, K.L. Organic Farming: Concept, Initiatives, Status and Implication. In Proceedings of the Padmanav Panda Memorial Oration at Orissa University of Agriculture \& Technology, Bhubaneswar, India, 25 July 2008.

8. Why Organic Farming has not Caught Up Yet in India. Available online: http://www.thehindubusinessline. $\mathrm{com} /$ markets/commodities/why-organic-farming-has-not-caught-up-yet-in-india/article6933518.ece (accessed on 25 February 2015).

9. Mitra, S.K. Organic tropical and subtropical fruit production in India-Prospects and challenges. Acta Hort. 2013, 975, 303-307. [CrossRef]

10. Indian Horticulture Database, 2014. National Horticulture Board, Ministry of Agriculture, Government of India: Gurgaon, India, 2015. Available online: http/ /www.nhb.gov.in (accessed on 25 October 2015).

11. Palanivel, V.; Muthukumar, C.M.; Gurusamy, M. A study on cultivation and marketing of mangoes in Krisnagiri district. Int. J. Adv. Eng. Recent Tech. 2015, 2, 31-43. 
12. Ingh, V.B.; Kanaujia, S.P. Vegetable Production Scenario in India. In Proceedings of the National Seminar on Sustainable Horticulture vis-à-vis Changing Environment, Dimapur District, India, 26-28 February 2016; The Horticultural Society of North-East India: Medziphema, India, 2015; pp. 73-82.

13. Garibay, S.V.; Jyoti, K. Market Opportunities and Challenges for Indian Organic Products. Available online: http:/ / www.orgprints.org/2684/1/garibay-2003-Market-Study-India.pdf (accessed on 25 October 2016).

(C) 2016 by the authors; licensee MDPI, Basel, Switzerland. This article is an open access article distributed under the terms and conditions of the Creative Commons Attribution (CC-BY) license (http:/ / creativecommons.org/licenses/by/4.0/). 